\title{
Modelling the Violation of Restrictions Pertaining to Deforestation in a Given Land Right
}

\author{
Anthony G. Tumba, Shahidah Bte Mohd Ariff \\ Faculty of Geoinformation and Real Estate, Universiti Teknologi Malaysia, Johor Bahru, Malaysia \\ Email: anthonytumba13@yahoo.com,Shahidah@utm.my
}

Received 30 September 2015; accepted 10 November 2015; published 13 November 2015

Copyright (C) 2015 by authors and Scientific Research Publishing Inc.

This work is licensed under the Creative Commons Attribution International License (CC BY).

http://creativecommons.org/licenses/by/4.0/

(c) (i) Open Access

\section{Abstract}

This paper develops a model that could be used to visualize and predict the violation of restrictions in a given forest. The violation of restriction in this case is assumed to be the difference in areal extent between two forest cover scenes with time; termed "deforestation". It analyses the relationship in forest cover changes overtime in Ganye Forest Reserve and Glide Cross Country Farm in Adamawa state, Nigeria. Cadastral maps of the forest reserve and farmland were used as the base maps, while the satellite images served as the spatio-temporal data. Landsat ETM+ images of 2003, 2008 and 2013 were used to identify, determine and estimate the violation of restrictions. The result shows that the violation of restrictions could be reliably determined for both the forest reserve and farmland and forecast made in order to predict future occurrence. It also revealed a continuous deforestation in the forest reserve, while in the farmland regeneration of forest stock was noticed. This information is very vital for forest management, planning and decision making in a viable land administration domain.

\section{Keywords}

Violation of Restrictions, Deforestation, Model, Land Right

\section{Introduction}

\subsection{Background}

The rights in a given forest are held through the natural processes of customary land rights or the government instituted statutory rights. Land right is an informal or formal claim to ownership of land, supported by tenure or 
duration [1]. Such right normally carries with it a stated condition for usage, that is, the restrictions which forbid the holder of the right from using it in a particular way. Restrictions are always imposed on any approved forest right, either in the forest reserves, individual or collective farmlands. The aim is to guard against any felling down of trees which could lead to deforestation; a term broadly used to refer to the cutting down or clearing of forest vegetation for the purpose of logging, oil and gas extraction, mining, cash crop production, fuelwood and cattle ranching [2]-[5]. In order to have a balance between nature and human development, forest right owners; be it individual, collective or otherwise is obliged to maintain the environmental friendliness of their entrusted parcel(s). This becomes imperative because of the importance of forest to our economies and its role in moderating our climate.

\subsection{The Problem}

The restrictions imposed on forest rights have never been so challenged as it is today in the management of forest. These challenges are in three forms; firstly, there is the challenge of determining the areal extent of violation of restrictions, secondly there is the problem of having a model that can continually be used to assess the violation of restrictions and thirdly, there is this desired need to have spatial data or information useful in the current land administration domain model (LADM) for the monitoring of these violations. Land administration systems (LASs) are a vital instrument of sustainable development and good governance. This good governance is provided through the concept of spatial data infrastructure (SDI) [6] [7], the land administration domain model (LADM) [1] and the property right infrastructures (PRI) [8]. These land administration systems provide services to the public [9] through availability of spatial information. In order to provide up-to-date reliable spatial information about violation of restrictions in any given land right, the spatio temporal forest information must be accurately identified, and reliably determined and estimated. The main aim of this study is to model the violation of restrictions pertaining to deforestation for effective implementation of people oriented land administration services with regards to forest protection. The objectives would be to develop a layer model from areal reality (images) based on time series change [10] and ground surveyed maps that could identify, determine and estimate violation of restrictions based on deforested areal extent and secondly, to provide a continuous monitoring model that could be used for planning and decision making.

\subsection{Study Area}

The study area is made up of a forest reserve (FR) and a farmland (FM) located in the Southern half of Adamawa State in Nigeria between latitudes $7^{\circ} 19^{\prime} 25^{\prime \prime} \mathrm{N}$ and $9^{\circ} 12^{\prime} 08^{\prime \prime} \mathrm{N}$ and longitudes $11^{\circ} 52^{\prime} 55^{\prime \prime} \mathrm{E}$ and $12^{\circ} 47^{\prime} 37^{\prime \prime} \mathrm{E}$ (Figure 1). The forest reserve has an area of about $59.12 \mathrm{~km}^{2}$ and is jointly under the control of the community and the state government, while the farmland is an area of about $0.397 \mathrm{~km}^{2}$ and is individually owned. These areas belong to the Tropical Savannah belt of the world. It has sub-regional classifications; like the Guinea Savannah, Sudan Savannah and so on. Its mean annual rainfall is between $900 \mathrm{~m}$ and $1100 \mathrm{~m}$, with a rainy season period lasting four (4) to five (5) months [11]. During the rainy seasons, the trees are ever green, in the dry seasons however, most of the trees shed their leaves to form patches of dry forests depending on their species.

\section{Overview of Deforestation}

The loss of forest cover as a result of deforestation is a major concern to the environmentalists the world over, studies by the Food and Agricultural Organization (FAO), International Tropical Timber Organization (ITTO) and the World Preservation Fund (WPF) have shown that the world has lost about $80 \%$ of its forest cover in recent time [12]-[15]. These declines in forest cover is attributed to be one of the major causes of climate change as a result of lack of adequate forest stock to absorb carbon and greenhouse gases (GHG) [16]. The International Panel on Climate Change (IPCC) estimates that $17 \%$ of global GHG are as a result of these changes in land use and forest cover loss [17]-[19]. Trees absorb greenhouse gases and carbon emissions; they eventually produce oxygen and perpetuate water cycle by releasing water vapour into the atmosphere. Aside from climate change, deforestation also leads to the exposure of the surface soil to the agents of denudation like weathering and soil erosion, thereby lynching untold hardship on animals and plants in the ecosystem. These untold hardships which are results of the effects of forest cover loss can be tackled by monitoring their restrictions using the instrument of land Right. 


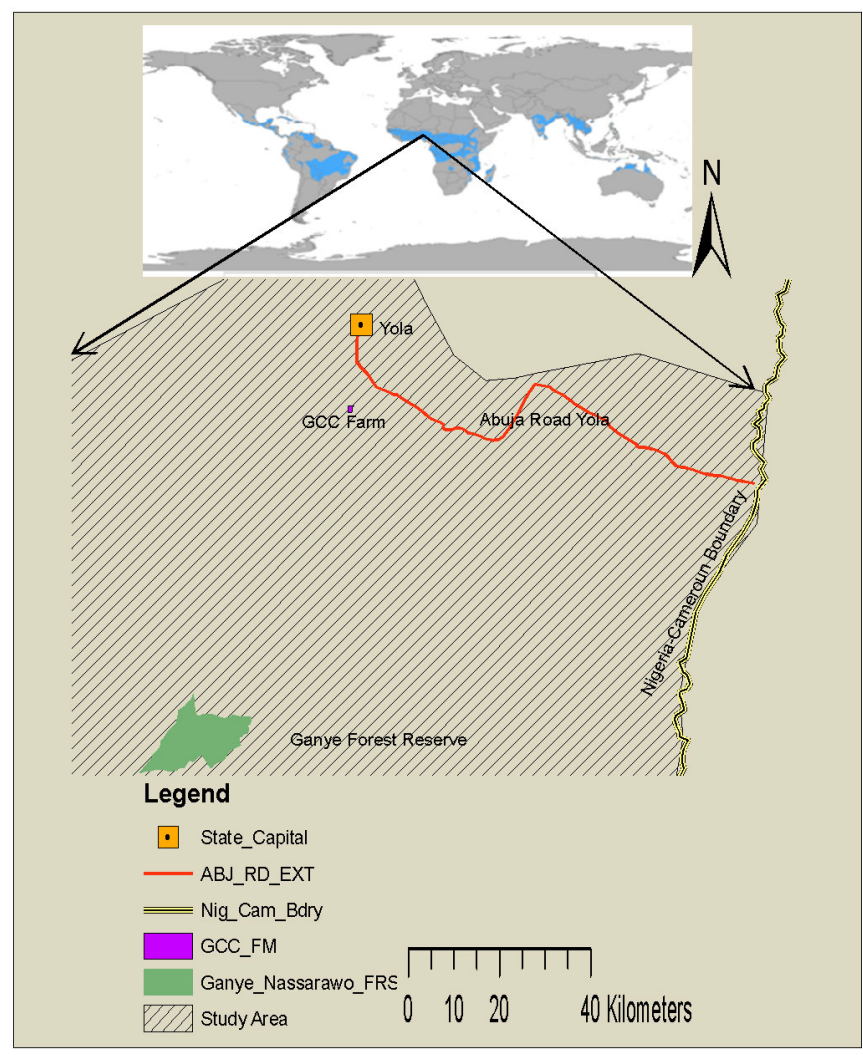

Figure 1. Study area location.

\subsection{Land Rights}

Land rights and tenure security have a positive relationship with deforestation and have been expressed by many environmentalists as having a tremendous influence on the management of the forest [20]-[22]. The security of land rights, and indeed forest is normally guaranteed by the land tenure and ownership pattern as defined by the property rights laws. The ownership of land, its tenure, and the control of the right over it determines the right over the use of its resources; this forms the basis for the rights in forest. The recognition of claim over forest, stating ownership and right of usage is a factor in determining forest security, and hence deforestation. Various jurisdictions have different considerations for approving and recognizing forest rights.

In the South America, where there is competition for land between the indigenous population, migrants and squatters [23] forest rights are hardly harmonized, for instance, in the case of Brazil, ownership rights of $12 \%$ is accorded to the indigenes with the rights of individual ownership recognized [24]. The Afro Brazilians have the rights to their "Quilombo", traditional land established by former slaves; also, squatters who have worked on a land for five years without being questioned can claim right to such land [20]-[25]. There is similarity in recognizing the indigenous (Tieras Communitarias de origen) and individuals right between Brazil and Bolivia, however, squatter and migrants rights have not been highlighted [26] [27], on the other hand, in Ecuador, squatters who have worked on a land for three years can have right over it. Private and individual rights are recognized, excluding ancestral lands [23].

In the Asia, diverse levels on tenurial rights were identified in Thailand. While there is recognition of community and individuals' rights in line with global norm, multiple registrations of the rights of families are allowed under the country's land code, foreigners are denied any right in land [28]). In Malaysia, individuals' rights are recognized, however, the ultimate right over land is held by the central government, with the states regulating these rights over their forest resources [29]. In Indonesia, land rights are not adequately defined. Although the Basic Agrarian Law (BAL) recognizes the customary land right, the "hak ulayat" under the customary law, the "adat", the registration of right does not convey conclusive right; it only serves as evidence of registration [30] [31]. 
In Africa, land ownership and tenure is complex, depending on the customary and colonial masters' statutory rights [32]. In the Democratic Republic of Congo (DRC), formerly known as the Belgian Congo, its 1973 land tenure law suppressed private ownership of rights, allowing customary rights over non allocated lands in the rural areas, however, of recent, community and individual rights are recognized [33] [34]. Ghana and Nigeria being countries colonized by Britain have similar recognition for customary and statutory rights. Customary land rights are recognized and held by the traditional "stools" (chiefs or family heads) [35]-[37]. However, forest rights are subject to modifications by the local and state authorities. In Nigeria for instance, the rights in forest are the prerogative of the three tiers of governments, the local, state and national. The rules governing forests, its areal extent, restrictions and penalties are vested in the local and state authorities on behalf of the central government [38] [39]. Therefore, land rights are jurisdiction specific and are given based on the peculiarity of the land administration practice in a place.

\subsection{Forest Restrictions}

In order to protect the forest from misuse leading to deforestation, restrictions are imposed on the forest and its resources, the imposition of these restrictions are case or jurisdiction-specific.

In the South America, Brazil has categorized their restrictions into two, the legal reserve restrictions (LR) and the Permanent Preservation Area restrictions (PPA). Forest restriction within the thick Amazon is $80 \%$, while in the savannah areas, $30 \%$ restriction is imposed, and $20 \%$ for rural property household. Restriction is also imposed on forests with slopes of $100 \%$ and with a height of $1.8 \mathrm{~m}$ above mean sea level, and on hilltops or mountain ridges comprising its 1/3 [24] [26]. Studies show that there is high level of uncertainty of rights and tenure security in forest in Bolivia that seem to down play restrictions, however, small family holdings are restricted to 50 hectares for agricultural cultivation [27]. In Ecuador, apart from the general law regulating cutting of forest, restrictions are imposed on sharecropping, a system in which land owners give out their land for cultivation in return for share of the produce [23].

In Asia, Thailand is identified as having absolute restriction on logging, by giving it a blanket ban. The country's land code as amended in 1999 imposed ceiling on the extent of land that individuals or group can own, from 0.8 hectares for residential to 8 hectares for agricultural lands [24] [28]. In Malaysia, restrictions are imposed on all forms of forest clearing [19] [40]. Restrictions are imposed on any removal of forest or its produce as well as the use of the forests' access roads. Only license holders are permitted to remove any portion or produce from the forest, which must be accompanied by a forest harvest plan [29]. In the case of Indonesia, there are laws in place restricting forest harvesting, logging and mineral exploitations, however imposition of restrictions are difficult because of irregularity in land registration occasioned by corruption [31].

In Africa, the DRC 2002 land code while granting rights to the customary communities imposed various restrictions on the use of the forest. Gathering of fruits is limited to 2 to $3 \mathrm{~km}$ range from the camps or residents, $30 \mathrm{~km}$ is approved for hunting range, which may be moved 4 to 6 times every year. Fallow for agricultural fields may extend up to $5 \mathrm{~km}$, while concession of up to 500,000 hectares is approved for timber exploitation [33]. In Ghana, restrictions are imposed on forests owned by traditional rights. Access is denied to forest trees or land in reserves except with clearance from the forest services division (FSD). The areal extent for the clearance or permit granted by the FSD is dependent on the operating laws of the traditional stool. Felled trees under the permit must be assessed for its market value within 48 hours by the FSD [35]. In Nigeria, forest management is decentralized [39] restrictions follow the general environmental protection laws against the felling of trees, however, the local government within which the forest falls determine the kind of restriction imposed [38]. However, the right to impose such restriction may be restricted or revoked by the governor, based on it, overriding public interest [36].

The diverse nature of approved land rights across the globe and the imposition of restrictions of different kinds on these rights emphasize the importance attached to monitoring forest rights in order to minimize the violation of these restrictive measures to protect the forest.

\section{Methodology}

\subsection{Data and Methods}

Ground Surveyed maps showing the areal extent of the forest reserve (Ganye Forest Reserve) at a scale of 
1/25,000 and the farmland (Glide Cross Country (GCC)) at a scale of 1/5000 form the base maps for this study. The forest reserve map was obtained from the Forestry Department of the Ministry of Environment, while that of the farmland was obtained from the Ministry of Lands and Survey, together with their attributes. These maps were obtained in analogue forms. ETM+ images covering the study area for 2003, 2008 and 2013 were downloaded from the United States geological survey website glovis.usgs.gov containing the information given below (Table 1).

\subsection{Analogue to Digital Conversion}

The first step to digital conversion was the scanning of these maps which made them easily compatible with the ArcGIS software.

Each of these analogue maps was imported into the ArcGIS 10.3 for Georeferencing. Georeferencing was done based on predetermined coordinates of identifiable selected points on the maps using the following projection parameters; WGS 1984, UTM Zone 33, Northern Hemisphere. Enough points were added in order to aid good insitu of position points and digitizing. The areas encompassing the forest reserve and farmland were digitized forming vector layer polygons which had hitherto been in raster format (Figure 2).

The digitized maps were then validated by adding them to the open street map (OSM); an editable online map of the globe initiated through the work of the Volunteered Geographic Information (VGI) services or crowdsourcing [41]-[44] so that their position and orientation could be corrected. Roads, village/town locations and other clearly identified points on the map were used for the validation.

\subsection{Pre-Processing of Satellite Images}

Preprocessing is done to correct image irregularities spectrally, radio metrically, spatially and geometrically before it can be finally fit for any classifications.

The 2003 and 2013 images, which can be termed, scan line corrector on (SLC-on), which means the scan line corrector was functional and did not reveal any scan gap were preprocessed for their spectral enhancement through composite bands or layer stacking, which enabled viewing of features from different spectral band combinations. This was done using the ERDAS IMAGINE 2014 software. They were spatially enhanced by statistical filtering which enable distinguishing of objects within a given space. Radiometric enhancement was done by applying the histogram equalization which maximizes contrast between pixel values.

The 2008 image is a SLC-Off image, which means the scan line corrector malfunctioned, needed to be spatially

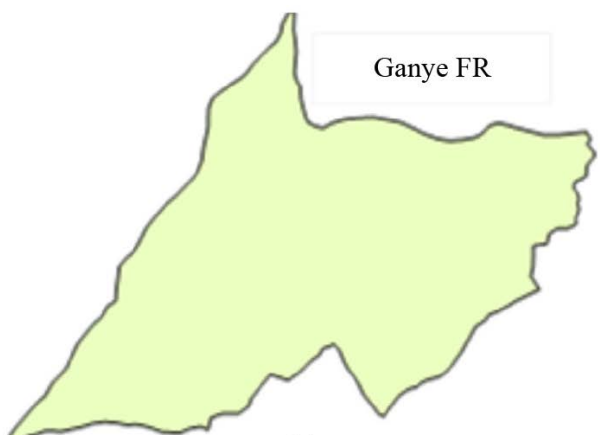

(a)
GCC FARM

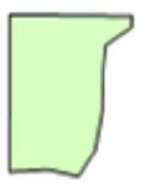

(b)

Figure 2. Digitized maps of forest reserve (a) and farmland (b).

Table 1. Satellite images information.

\begin{tabular}{cccc}
\hline Year & Path/Row & Band Combination & $\begin{array}{c}\text { Acquisition } \\
\text { Date }\end{array}$ \\
\hline 2003 & $185 / 54$ & $4,3,2$ & $19 / 01 / 2003$ \\
2008 & $185 / 54$ & $4,3,2$ & $18 / 02 / 2008$ \\
2013 & $185 / 54$ & $5,4,3$ & $12 / 04 / 2013$ \\
\hline
\end{tabular}


corrected before any other enhancement can be carried out. Although there have been reservations about the scientific applications of SLC-Off images, it has been proven to be useful in forest and vegetation studies [45]-[47] after due enhancement is made through gap filling. The enhancement of the missing gaps was done by applying the "Focal Analysis" correction in REDAS IMAGINE 2014. This was done through numerous iterations processes which entirely depend on the neighbourhood pixels for its iteration parameters.

\subsection{Processing of Satellite Images}

The final process of processing the satellite imageries were done by classifying the images into various themes. The first step involved the use of pre-selected training sites to obtain the average spectral values or digital numbers (DN) that would be used for the classification. These sites were selected during "ground truthing" or site visitation, a process normally used to validate classification accuracy. In the ERDAS IMAGINE 2014, polygon signatures were created for the classes of water body, green forest, dry forest, built-up areas, mountains/outcrops and bare soil (Figure 3). In all, six signatures were obtained. Supervised classification was carried out using the maximum likelihood classification to obtain a thematic map of the stated classes.

Accuracy evaluation was carried on the classified images using the reflectance value of the ground truthed sample sites signatures. The error matrix show insignificant errors which cannot significantly affect the accuracy of the classified themes (Table 2-4).

\subsection{Image Integration}

The superimposition of the digitized and validated shape file maps of the study areas on the satellite images in ERDAS IMAGINE 2014 to create their subsets was the first form of data integration.

In order to simplify the excesses of having too much vector polygons for parcel conversion and editing, Adamawa state and the selected study sites within it were carved out of the main raster image scenes as subsets or

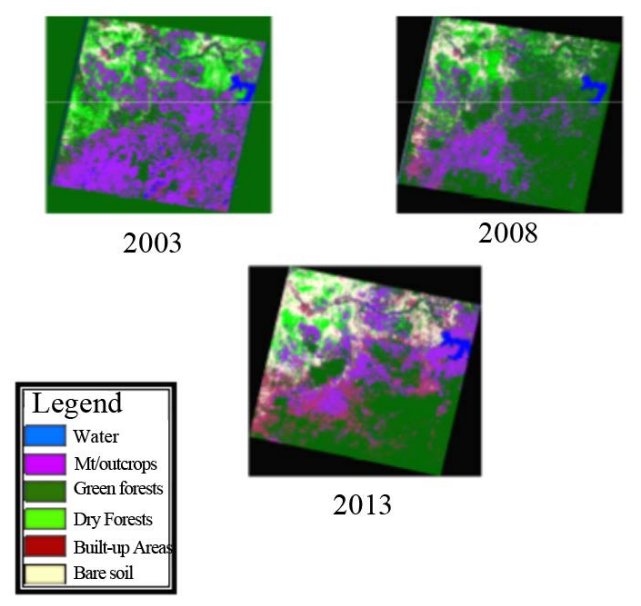

Figure 3. Classified images of 2003, 2008 and 2013.

Table 2. Error matrix for classified 2003 images.

\begin{tabular}{|c|c|c|c|c|c|c|c|}
\hline Classified Data & Green Forest & Dry Forest & Bare Soil & Built-up A & Water & MT-Outcrop & Row Total \\
\hline Green Forest & 489 & 0 & 0 & 1 & 8 & 0 & 498 \\
\hline Dry Forest & 0 & 77 & 0 & 0 & 0 & 0 & 77 \\
\hline Bare Soil & 0 & 0 & 386 & 0 & 0 & 0 & 0 \\
\hline Built-up A & 0 & 0 & 0 & 2437 & 16 & 0 & 2453 \\
\hline Water & 0 & 0 & 0 & 0 & 1500 & 0 & 1500 \\
\hline MT-Outcrop & 0 & 0 & 0 & 0 & 0 & 1573 & 1573 \\
\hline Row Total & 489 & 77 & 386 & 2438 & 1524 & 1573 & 6487 \\
\hline
\end{tabular}


Table 3. Error matrix for classified 2008 images.

\begin{tabular}{cccccccc}
\hline Classified Data & Green Forest & Dry Forest & Water & Built-up A & Bare Soil & MT-Outcrop & Row Total \\
\hline Green Forest & 1072 & 1 & 26 & 11 & 1 & 7 & 1118 \\
Dry Forest & 2 & 903 & 0 & 0 & 0 & 0 & 905 \\
Water & 0 & 0 & 2213 & 0 & 0 & 0 & 2213 \\
Built-up A & 0 & 0 & 4 & 3420 & 0 & 0 & 3424 \\
Bare Soil & 0 & 0 & 0 & 14 & 1147 & 0 & 1161 \\
MT-Outcrop & 0 & 0 & 0 & 0 & 0 & 4416 & 4416 \\
Row Total & 1074 & 904 & 2243 & 3445 & 1148 & 4423 & 13,237 \\
\hline
\end{tabular}

Table 4. Error matrix for classified 2013 images.

\begin{tabular}{cccccccc}
\hline Classified Data & Green Forest & Dry Forest & Built-up A & Bare Soil & MT-Outcrop & Water & Row Total \\
\hline Green Forest & 3832 & 0 & 0 & 0 & 0 & 10 & 3842 \\
Dry Forest & 1 & 378 & 0 & 0 & 0 & 0 & 379 \\
Built-up A & 0 & 0 & 1760 & 0 & 0 & 95 & 1855 \\
Bare Soil & 0 & 0 & 0 & 1202 & 0 & 0 & 1202 \\
MT-Outcrop & 0 & 0 & 0 & 0 & 1050 & 4 & 1054 \\
Water & 0 & 0 & 0 & 0 & 0 & 106,332 & 106,332 \\
Row Total & 3833 & 378 & 1760 & 1202 & 1050 & 106,441 & 114,664 \\
\hline
\end{tabular}

areas of interest (AOIs) (Figure 4). The subsets were then converted to vector layers to make them easy to extract as individual themes in the ArcGIS 10.3 environment.

\subsection{Feature Merging, Extraction and Differencing}

The extraction of the themes into vector parcel polygons was done in ArcGIS 10.3 using the attribute table. In the attribute table, a theme is selected based on its "value" (thematic value based on classification) and exported to the data frame to be saved in a choice folder. This process was carried out for each of the image scenes, to produce less complicated vector polygons that could be used for thematic parcel merging, extraction (clipping) and differencing (overlay).

Since the main interest of the study is the forest, the different kinds of forests were merged into a single polygon theme, "forest". Clipping is done to detect changes in aft and prior polygon features; it shows where changes have occurred and where they have not through area intersections. Differencing of the polygons (forest) was carried to show changes that have occurred between the first and the second image.

\section{Results}

\section{Determining Violation of Restriction}

The violation of restrictions is determined through the identification and the estimation of areal extent change between successive forest covers. For the three periods of 2003, 2008 and 2013 under study, the images in Figure 5 and Figure 6 are extracts for the forest reserve and farmland respectively. Only classified themes that fall within the area are automatically extracted.

The numerical values and percentage of these extracted polygons are presented in Tables 5-7 for the forest reserve.

Summarizing Tables 5-7 for the parcel values of the green and dry forests, in order to get the total forest cover for the three periods give the values in Table 8 . 


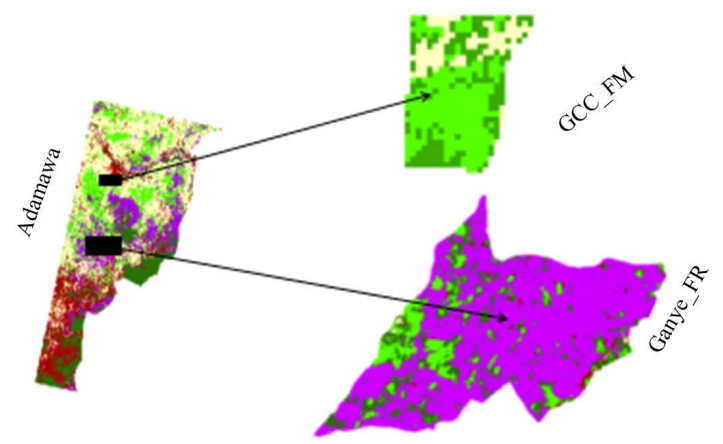

Figure 4. Subsets of study areas.
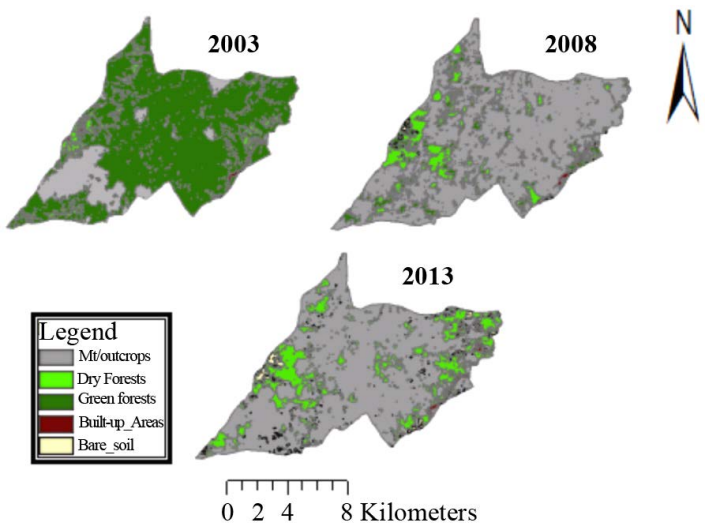

Figure 5. Extracted thematic parcels of ganye forest reserve; 2003, 2008, and 2013.
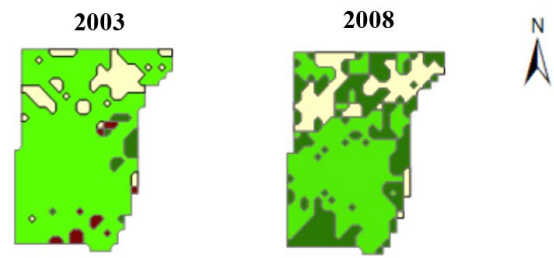

2013
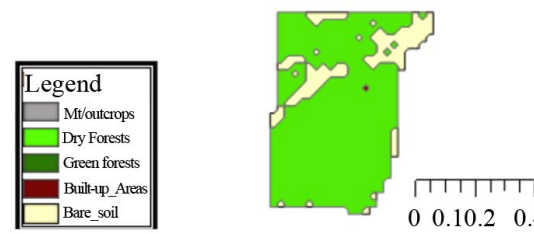

$0 \quad 0.10 .2 \quad 0.4$ Kilometers

Figure 6. Extracted thematic parcels for GCC farm; 2003, 2008, and 2013.

Table 5. 2003 forest reserves thematic parcels.

\begin{tabular}{cccccc}
\hline OID & Value & Count Value & Sum_Area_Sqm & P_Cent & Class_name \\
\hline 0 & 3 & 181 & $46,781,899$ & 78 & Green Forest \\
1 & 4 & 808 & $3,598,658$ & 6 & Dry Forest \\
2 & 5 & 48 & 109,130 & 0 & Bare Soil \\
3 & 6 & 183 & 603,360 & 1 & Built-up Area \\
4 & 8 & 246 & $8,619,761$ & 14 & Mt_Outcrop \\
\hline
\end{tabular}


Table 6. 2008 forest reserves thematic parcels.

\begin{tabular}{cccccc}
\hline OID & Value & Count Value & Sum_Area_Sqm & P_Cent & Class_Name \\
\hline 0 & 3 & 1325 & $9,183,534$ & 15 & Green Forest \\
1 & 4 & 353 & $5,686,115$ & 10 & Dry Forest \\
2 & 6 & 224 & 786,503 & 1 & Built-up Area \\
3 & 7 & 36 & 207,342 & 0 & Bare Soil \\
4 & 8 & 176 & $43,845,760$ & 73 & Mt_Outcrop \\
\hline
\end{tabular}

Table 7. 2013 forest reserves thematic parcels.

\begin{tabular}{cccccc}
\hline OID & Value & Count Value & Sum_Area_Sqm & P_Cent & Class_Name \\
\hline 0 & 3 & 168 & 506,266 & 1 & Green Forest \\
1 & 4 & 164 & 493,448 & 1 & Built-up Area \\
2 & 6 & 478 & $10,568,146$ & 18 & Dry Forest \\
3 & 7 & 417 & $2,010,053$ & 3 & Bare Soil \\
4 & 8 & 263 & $46,132,893$ & 77 & Mt_Outcrop \\
\hline
\end{tabular}

Table 8. Summary of extracted forest reserve forests parcels.

\begin{tabular}{cccc}
\hline Class Name & $\mathbf{2 0 0 3}$ & $\mathbf{2 0 0 8}$ & $\mathbf{2 0 1 3}$ \\
\hline Green Forest & $46,781,899 \mathrm{~m}^{2}$ & $9,183,534 \mathrm{~m}^{2}$ & $506,266 \mathrm{~m}^{2}$ \\
Dry Forest & $3,598,658 \mathrm{~m}^{2}$ & $5,686,115 \mathrm{~m}^{2}$ & $10,568,146 \mathrm{~m}^{2}$ \\
Total & $\mathbf{5 0 , 3 8 0 , 5 5 7} \mathbf{~ m}^{2}$ & $\mathbf{1 4 , 8 6 9 , 6 4 9} \mathbf{~ m}^{2}$ & $\mathbf{1 1 , 0 7 4 , 4 1 2} \mathbf{~ m}^{2}$ \\
\hline
\end{tabular}

In a similar manner, the numerical values and percentage of these extracted polygons parcels for the farmland are presented in Tables 9-11.

The summary of extracted forest parcels from Tables $9-11$ for the farmland is given in Table 12 for the three periods.

\section{Discussion}

\subsection{Modelling Restrictions}

In modelling Restrictions pertaining to deforestation, the "process approach" is used. Chen [48] refers to process as "the sequence of changes in space and time" and used this process in modelling spatial and temporal variations in urban growth, similar process was also used by Al jabber [10] to detect vegetation cover change in Dhaka city. Change in space is "spatial variation", and it moves along with time (temporal variation) [48]. In our model, assumption is made that the differences in forest cover between two image scenes for a particular area at a given time constitute violation of restrictions.

\subsection{Forest Reserve Restrictions}

The violation of restrictions between 2003 and 2008 for Ganye forest Reserve is given by the total sum difference of polygon parcels between the two periods (Figure 7).

Similarly, the violation of restrictions for the period between 2008 and 2013 can also be obtained by the difference in the forest cover between these periods (Figure 8).

In a similar manner, the total forest cover (green + dry) for the three periods of 2003, 2008 and 2013 as summarized in Table 12 can be rearranged to give the figures in Table 13 for the forest reserve.

Plotting these values give a clear picture of the trends in the forest cover as shown in Figure 9. 


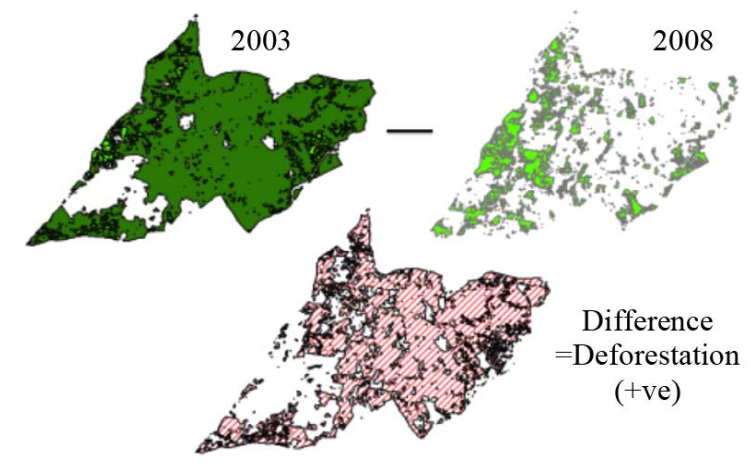

Figure 7. Violation of restriction between 2003 and 2008.

Table 9. Summary of 2003 farmland thematic parcels.

\begin{tabular}{cccccc}
\hline OID & Value & Count Value & Sum_Area_Sqm & P_Cent & Class_Name \\
\hline 0 & 3 & 6 & 12,600 & 3 & Green Forest \\
1 & 4 & 2 & 362,925 & 83 & Dry Forest \\
2 & 5 & 15 & 52,089 & 12 & Bare Soil \\
3 & 6 & 8 & 11,476 & 3 & Built-up Area \\
\hline
\end{tabular}

Table 10. Summary of 2008 farmland thematic parcels.

\begin{tabular}{cccccc}
\hline OID & Value & Count Value & Sum_Area_Sqm & P_Cent & Class_Name \\
\hline 0 & 3 & 40 & 133,543 & 30 & Green Forest \\
1 & 4 & 9 & 222,637 & 51 & Dry Forest \\
2 & 7 & 6 & 82,463 & 19 & Bare Soil \\
\hline
\end{tabular}

Table 11. Summary of 2013 farmland thematic parcels.

\begin{tabular}{cccccc}
\hline OID & Value & Count Value & Sum_Area_Sqm & P_Cent & Class_Name \\
\hline 0 & 4 & 1 & 450 & 0 & Built-up Area \\
1 & 6 & 5 & 364,725 & 83 & Dry Forest \\
2 & 7 & 14 & 73,801 & 17 & Bare Soil \\
\hline
\end{tabular}

Table 12. Summary of extracted farmland forests parcels.

\begin{tabular}{|c|c|c|c|}
\hline Class Name & 2003 & 2008 & 2013 \\
\hline Green Forest & $12,600 \mathrm{~m}^{2}$ & $133,543 \mathrm{~m}^{2}$ & \\
\hline Dry Forest & $362,925 \mathrm{~m}^{2}$ & $222,637 \mathrm{~m}^{2}$ & $364,725 \mathrm{~m}^{2}$ \\
\hline Total & $375,525 \mathrm{~m}^{2}$ & $356,280 \mathrm{~m}^{2}$ & $364,725 \mathrm{~m}^{2}$ \\
\hline
\end{tabular}

Table 13. Ganye reserve forest cover.

\begin{tabular}{lll}
\hline Forest Cover & Year \\
\hline $50,380,557 \mathrm{~m}^{2}$ & 2003 \\
$14,869,649 \mathrm{~m}^{2}$ & 2008 \\
$11,074,412 \mathrm{~m}^{2}$ & 2013 \\
\hline
\end{tabular}




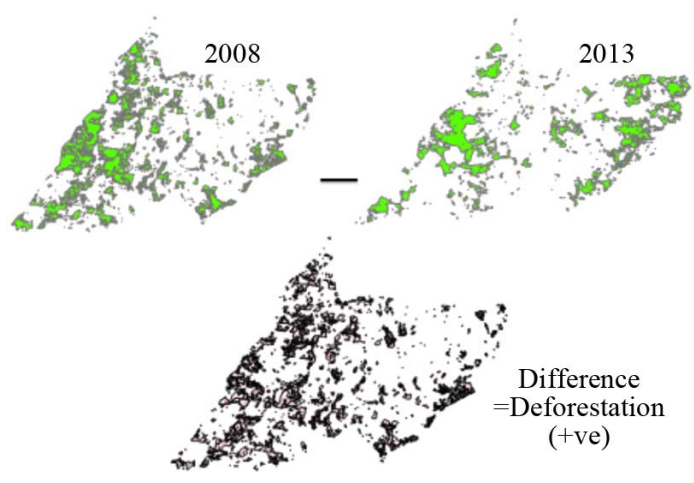

Figure 8. Violation of restriction between 2008 and 2013.

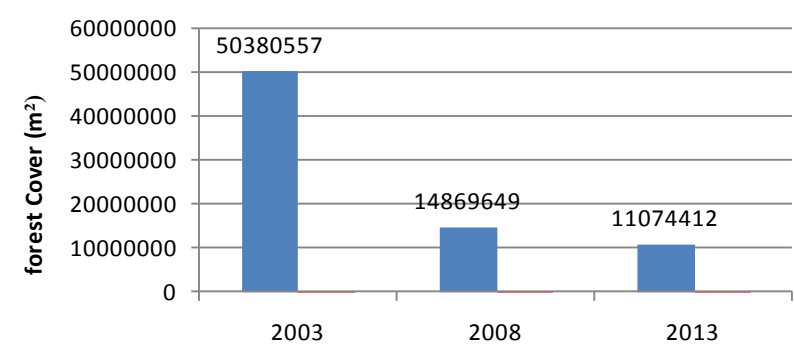

Figure 9. Plot of forest cover against year (FR).

The areal extent or amount of violation of restrictions (deforestation) can be estimated by subtracting the value of the later from the former or previous cover. This areal extent, which is actually the deforestation, is shown in red against the preceding year's (PY) value in blue (Figure 10). It is observed from the chart that the violation of restrictions for the periods between 2003 and 2008 in the forest reserve is 35,510,908 $\mathrm{m}^{2}$, while that between 2008 and 2013 is $3,795,237 \mathrm{~m}^{2}$.

\subsection{Farmland Restrictions}

The violation of restrictions in farmland is determined through the same process as shown in the data and processes below (Figure 11 and Figure 12), for the period between 2003 and 2008, and that between 2008 and 2013.

Applying the same procedure as that of the forest reserve, the values of forest cover for the farmland for the periods of 2003, 2008 and 2013 were rearranged to obtain a summarized forest cover shown in Table 14.

Plotting these values give the chart in Figure 13.

The areal extent or amount of violation of restrictions (deforestation) in the farmland is shown in Figure 14. Deforestation is shown in green against the preceding year's (PY) value in red. However, it is observed that the deforestation that is supposed to be shown on the 2008 column is being shown less (-ve) under the 2013 column which confirms the findings in Figure 12. This shows that there was an increase in forest stock or cover over the five-year period rather than decrease. This might be due to regeneration or planting of trees in the farmland.

Thus, the amount of violation of restrictions between 2003 and 2008 is put at $19245 \mathrm{~m}^{2}$, while between the periods of 2008 and 2013; there was improvement in forest cover of $8445 \mathrm{~m}^{2}$. This does not however indicate that there was no deforestation between these periods.

\subsection{Evaluation of the Restriction Models}

The usefulness and validity of the models are tested by using Pearson linear regression to analyze the directionality and correlation of the data. Regression analysis gives the relationship between two (or more) variables; one called the response variable and the other called the explanatory or predictor variable [49]. The response variable is the dependent variable, while the predictor is the independent variable $(y=a+b x+E)$. Where $y=$ dependent variable, $a=y$ intercept (constant term), $b=$ the slope gradient of $x$, and $E=$ error term. 


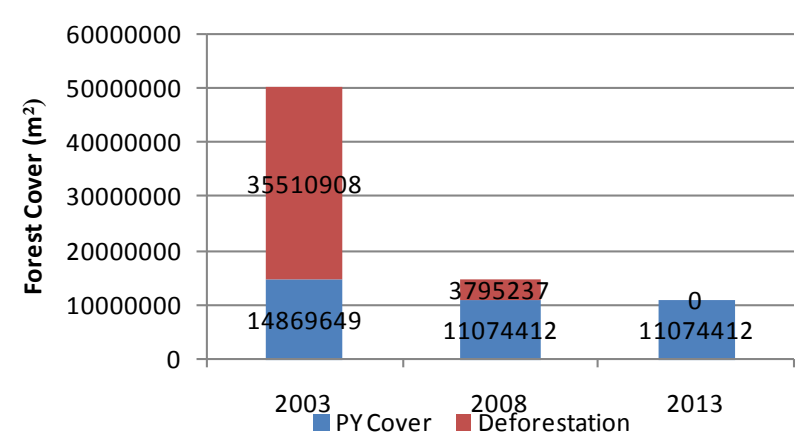

Figure 10. Plot showing deforestation between 2003, 2008 and 2013.

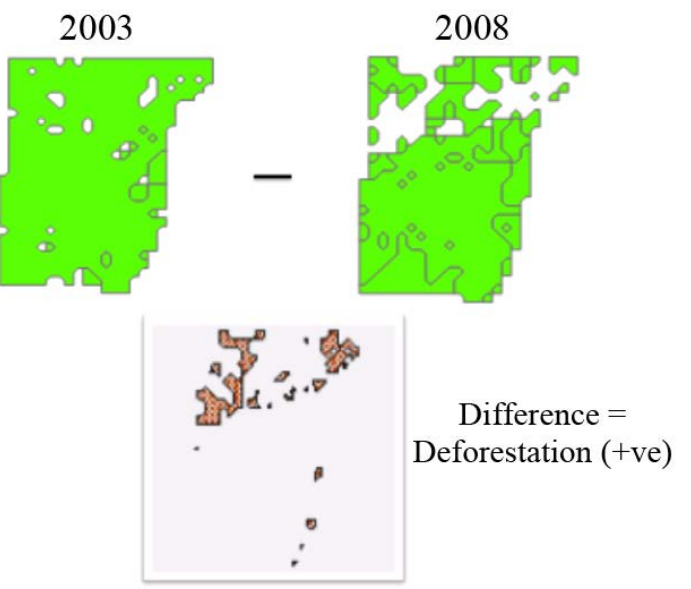

Figure 11. Violation of restriction (FM) between 2003 and 2008.
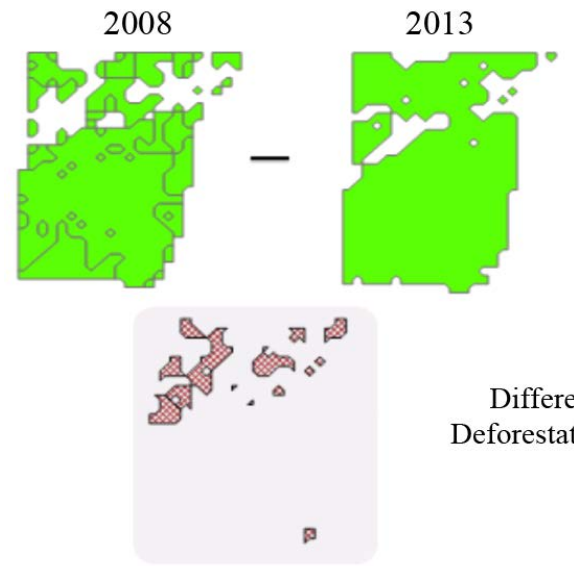

Difference $=$

Deforestation (-ve)

Figure 12. Violation of restriction (FM) between 2008 and 2013.

In the case of this research, the temporal data (years) is the independent variable $(x)$ that is used to predict the spatial data or information (forest cover) which is the dependent variable $(y)$. Understanding the relationship between these variables is important in order that future predictions may be made by simple forecasting.

This simple forecasting for the forest reserve predicts a negative value for $2018\left(-13,864,605.67 \mathrm{~m}^{2}\right)$ (Table 15). 


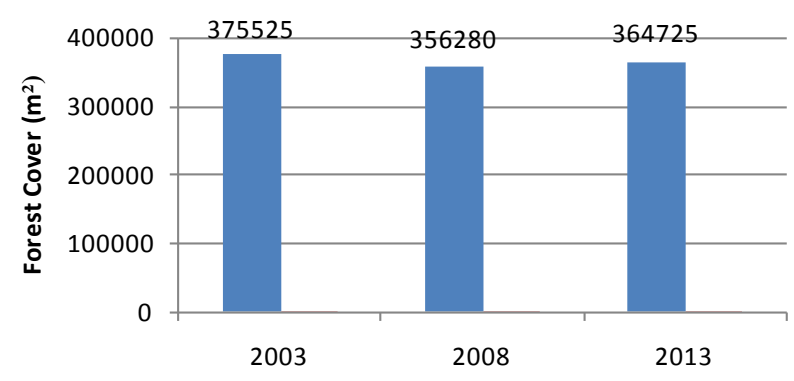

Figure 13. Plot of forest cover against year (FM).

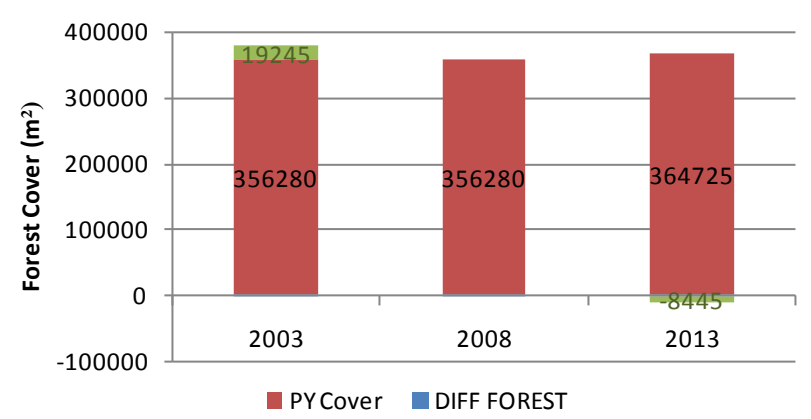

Figure 14. Plot showing deforestation (FM) between 2003, 2008 and 2013.

Table 14. GCC farmland forest cover.

\begin{tabular}{cc}
\hline Forest Cover & Year \\
\hline $375,525 \mathrm{~m}^{2}$ & 2003 \\
$356,280 \mathrm{~m}^{2}$ & 2008 \\
$364,725 \mathrm{~m}^{2}$ & 2013 \\
\hline
\end{tabular}

Table 15. Forest reserve cover forecast for 2018.

\begin{tabular}{ccc}
\hline & Forest Cover & Year \\
\hline Forecast & $50,380,557 \mathrm{~m}^{2}$ & 2003 \\
& $14,869,649 \mathrm{~m}^{2}$ & 2008 \\
& $11,074,412 \mathrm{~m}^{2}$ & 2013 \\
& $\underline{\mathbf{- 1 3 8 6 4 6 0 5 . 6 7} \mathbf{~ m}^{\mathbf{2}}}$ & $\underline{\mathbf{2 0 1 8}}$ \\
\hline
\end{tabular}

This means that by 2018 we would reach an emergency situation where the entire forest reserve would have turned to desert. To buttress this argument, the graph of correlation (Figure 15) shows there is a perfect negative correlation $\left(\mathrm{R}^{2}=0.9201\right)$ between the independent variable (temporal) and the dependent variable (spatial). The line of best fit slanting from right to left indicates that deforestation increases with time; it also shows that the values used in determining the violation of restriction are clustered around the line of best fit. This information is vital for planning and making future decisions on ways to curb the impending danger.

In the case of the farmland, the forecast predicts a positive deforestation value of $354,710 \mathrm{~m}^{2}$ (Table 16) with a weak determinant of correlation, $\mathrm{R}^{2}=0.5329$. This means that a situation may arise where instead of decreasing, forest cover may increase as shown by the sinusoidal nature of the curve (Figure 16).

\section{Findings}

Findings from the research show that the pattern of deforestation or violation of restrictions in the forest reserves 


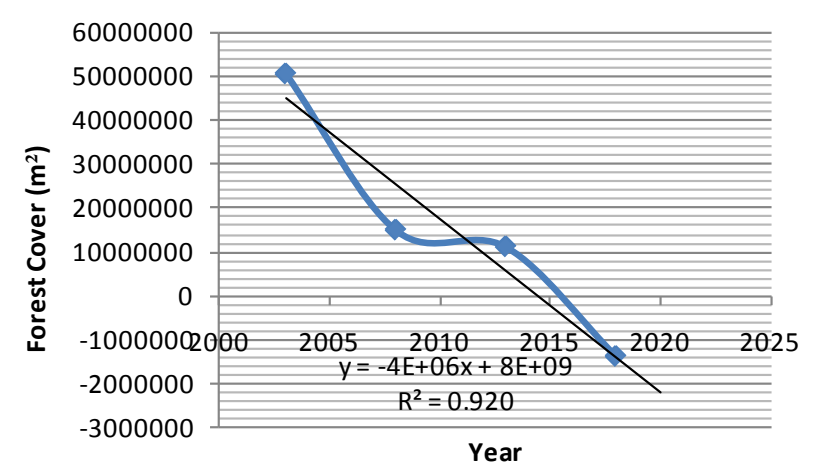

Figure 15. Graph of forest cover against year (FR).

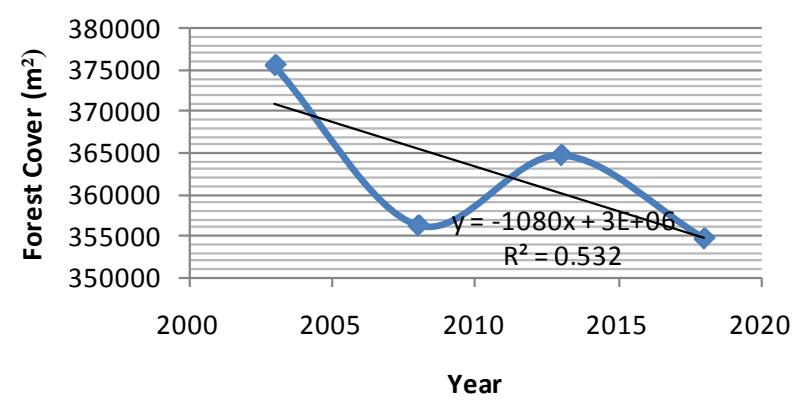

Figure 16. Graph of forest cover against year (FM).

Table 16. Farmland forest cover forecast for 2018.

\begin{tabular}{|c|c|c|}
\hline & Forest Cover & Year \\
\hline \multirow{4}{*}{ Forecast } & $375,525 \mathrm{~m}^{2}$ & 2003 \\
\hline & $356280 \mathrm{~m}^{2}$ & 2008 \\
\hline & $364,725 \mathrm{~m}^{2}$ & 2013 \\
\hline & $\underline{354,710 \mathrm{~m}^{2}}$ & $\underline{2018}$ \\
\hline
\end{tabular}

and farmland while having similar pattern of continuous scattered deforestation differ in the following ways;

- There is a continuous sharp decline in forest cover in the forest reserve owned by the government/community that threatens the entire ecosystem as indicated by the emergency situation occasioned by the negative value (-) for 2018 forecast.

- In the farmland, owned by individual/group, there is opportunity for improvement in forest stock through regeneration over time as indicated in the forest cover for 2013.

\section{Conclusion}

This study highlights on the modelling of violation of restrictions pertaining to deforestation in a given land right. The model focuses on the use of in situ surveyed ground data in conjunction with aerial realities to provide information on the extent of forest cover change over time, useful for determining and estimating the violation of restrictions. The Ganye Forest Reserve and Glide Cross Country Farm in Adamawa state, Nigeria were used as the study sites. The result of the violation of restrictions in the forest reserve and farmland showed similar downward trend in forest cover with time, however, it was noticed that forest regeneration is possible in the farmland, perhaps because of its size and the type of land right (individual ownership). Conclusively, the research shows that it is quite possible to use accurately surveyed data and aerial images to estimate and predict violation of restrictions in any given land right. The central aim is to provide a model that could be able to continually visualize and predict violation of restrictions for decision making in forest management and planning. 


\section{References}

[1] Lemmen, C., Oosterom, P.V., Eisenhut, C. and Uitermark, H. (2010) The Modelling of Rights, Restrictions and Responsibilities (RRR) in the Land Administration Domain Model (Ladm). Facing the Challenges-Building the Capacity. FIG Congress Sydney, Australia, 11-16 April 2010.

[2] Kricher, J.C. (1997) A Neotropical Companion: An Introduction to the Animals, Plants and Ecosystems of the New World Tropics. J. C. Princeton University Press, Princeton.

[3] FAO (2000) On Definitions of Forest and Forest Change. Forest Resources Assessment Programme, Working Paper 33, Rome 2000.

[4] Mahbub Uddin Ahmed, A.I. (2008) Underlying Causes of Deforestation and Forest Degradation in Bangladesh. A Report Submitted to the Global Forest Coalition (GFC), The Netherlands. http://vh-gfc.dpi.nl/img/userpics/File/UnderlyingCauses/Bangladesh-Report-Underlying-Causes-Workshops.pdf

[5] Chan, S. and Sasaki, N. (2014) Assessment of Drivers of Deforestation and Forest Degradation in Phnom Tbeng Forest Based on Socio-Economic Surveys. Journal of Environmental Protection, 5 1641-1653. http://dx.doi.org/10.4236/jep.2014.517155

[6] Bregt, A., Crompvoets, J., De Man, E. and Grus, L. (2009) Challenges in Spatial Data Infrastructure Research: A Role for Transdisciplinarity? GSDI 11 Spatial Data Infrastructure Convergence: Building SDI Bridges to Address Global Challenges, Rotterdam, 15-19 June 2009.

[7] Craglia, M., De Bie, K., Jackson, D., Pesaresi, M., Remetey-Fülöpp, G., Wang, C., Annoni, A., Bian, L., Campbell, F., Ehlers, M., Van Genderen, J., Goodchild, M., Guo, H., Lewis, A., Simpson, R., Skidmore, A. and Woodgate, P. (2012) Digital Earth 2020: Towards the Vision for the Next Decade. International Journal of Digital Earth, 5, 4-21. http://dx.doi.org/10.1080/17538947.2011.638500

[8] Bennett, R., Tambuwala, N., Rajabifard, A., Wallace, J. and Williamson, I. (2013) On Recognizing Land Administration as Critical, Public Good Infrastructure. Land Use Policy, 30, 84-93. http://dx.doi.org/10.1016/j.landusepol.2012.02.004

[9] Kalantari, M., Rajabifard, A., Wallace, J. and Williamson, I. (2008) Spatially Referenced Legal Property Objects. Land Use Policy, 25, 173-181. http://dx.doi.org/10.1016/j.landusepol.2007.04.004

[10] Aljaber, S., Ghosh, A.K. and Mahmud, M.S. (2014) Using Time Series of Satellite Images to Detect Vegetation Cover Change in Dhaka City. Journal of Geographic Information System, 6, 653-663. http://dx.doi.org/10.4236/jgis.2014.66054

[11] Akosim, C., Tella, I.O. and Jatau, D.F. (1998) Vegetation and Forest Resources. In: Adebayo, A.A. and Tukur, A.L., Eds., Adamawa State in Maps, Paraclete Publishers, Yola, 32.

[12] ITTO (2009) Monitoring Deforestation, Logging and Land Use Change in the Pan Amazonia Forest-PanamazonII. http://www.itto.int/files/itto_project_db_input/2980/Project/RED_PD_029_09_Rev\%201_F_ProjectDocument_Final.p $\underline{\mathrm{df}}$

[13] FAO (2010) Global Forest Land-Use Change from 1990 to 2010: An Update to a Global Remote Sensing Survey of Forests. http://foris.fao.org/static/data/fra2010/RSS2010update.pdf

[14] WPF (2010) Deforestation Statistics. World Preservation Foundation. http://www.worldpreservationfoundation.org/blog/news/deforestation-statistics/\#.U7USu7G8TZc

[15] Portillo-Quintero, C.A., Sanchez, A.M., Valbuena, C.A., Gonzalez, Y.Y. and Larreal, J.T. (2012) Forest Cover and Deforestation Patterns in the Northern Andes (Lake Maracaibo Basin): A Synoptic Assessment Using Modis and Landsat Imagery. Applied Geography, 35, 152-163. http://dx.doi.org/10.1016/j.apgeog.2012.06.015

[16] Buizer, M., Humphreys, D. and De Jong, W. (2014) Climate Change and Deforestation: The Evolution of an Intersecting Policy Domain. Environmental Science \& Policy, 35, 1-11. http://dx.doi.org/10.1016/j.envsci.2013.06.001

[17] Albani, M., Oppenheim, J., Riese, J. and Schwarz, A. (2012) Reducing Deforestation: The Land-Use Revolution. McKinsey on Sustainability \& Resource Productivity Summer 2012.

http://www.mckinsey.com/ /media/mckinsey/dotcom/client_service/Sustainability/PDFs/McK\%20on\%20SRP/SRP_1 $\underline{0 \text { Deforestation.ashx }}$

[18] Cacho, O.J., Milne, S., Gonzalez, R. and Tacconi, L. (2014) Benefits and Costs of Deforestation by Smallholders: Implications for Forest Conservation and Climate Policy. Ecological Economics, 107, 321-332. http://dx.doi.org/10.1016/j.ecolecon.2014.09.012

[19] Overmars, K.P., Stehfest, E., Tabeau, A., Van Meijl, H., Beltrán, A.M. and Kram, T. (2014) Estimating the Opportunity Costs of Reducing Carbon Dioxide Emissions Via Avoided Deforestation, Using Integrated Assessment Modelling. Land Use Policy, 41, 45-60. http://dx.doi.org/10.1016/j.landusepol.2014.04.015

[20] Araujo, C., Bonjean, C.A., Combes, J.-L., Motel, P.C. and Reis, E.J. (2010) Does Land Tenure Insecurity Drive De- 
forestation in the Brazilian Amazon? http://www.cerdi.org/uploads/pagePerso/28/2010.13.pdf

[21] Robinson, B.E., Holland, M.B. and Naughton-Treves, L. (2011) Does Secure Land Tenure Save Forests? A Review of the Relationship between Land Tenure and Tropical Deforestation. Working Paper No. 7. CGIAR Research Program on Climate Change, Agriculture and Food Security (CCAFS), Copenhagen. http://www.ccafs.cgiar.org

[22] Sunderlin, W.D., Larson, A.M., Duchelle, A.E., Resosudarmo, I.A.P., Huynh, T.B., Awono, A. and Dokken, T. (2014) How Are REDD+ Proponents Addressing Tenure Problems? Evidence from Brazil, Cameroon, Tanzania, Indonesia, and Vietnam. World Development, 55, 37-52. http://dx.doi.org/10.1016/j.worlddev.2013.01.013

[23] USAID (2011) Property Rights and Resource Governance in Ecuador. http://usaidlandtenure.net/sites/default/files/country-profiles/full-reports/USAID_Land_Tenure_Ecuador_Profile.pdf

[24] Ribeiro, C.A.A.S., Soares, V.P., Gleriani, J.M., Chaves, M.D.Á., Lorenzon, A.S., Barros, K.D.O., Costa, F.R., Marcatti, G.E., Castro, N.L.M.D., Domingues, G.F. and Oliveira, J.D.C. (2013) Brazilian Forest Code: An Intriguing Framework for Designing Worldwide Protected Areas. http://www.earsel.org/symposia/2013-symposium-Matera/pdf_proceedings/EARSeL-Symposium-2013_1_1_ribeiro.pd f

[25] USAID (2012) Property Rights and Resource Governance in Brazil. http://usaidlandtenure.net/sites/default/files/country-profiles/full-reports/USAID_Land_Tenure_Brazil_Profile.pdf

[26] Pacheco, P. (2005) Law Compliance: Bolivia Case Study. http://www.fao.org/forestry/19583-06647b501b992f13fa80edbbb8942712c.pdf

[27] USAID (2014) Property Rights and Resource Governace in Bolivia. http://www.usaidlandtenure.net/sites/default/files/country-profiles/full-reports/USAID_Land_Tenure_Bolivia_Profile.p df

[28] USAID (2010) Property Rights and Resource Governance in Thailand. http://usaidlandtenure.net/sites/default/files/country-profiles/full-reports/USAID_Land_Tenure_Thailand_Profile.pdf

[29] NFAM (2006) Laws of Malaysia: National Forestry Act 1984. http://www.agc.gov.my/Akta/Vol.\%207/Act\%20313.pdf

[30] Wright, G. (2011) Indegenous People and Customary Land Ownership under Domestic Redd+ Frameworks: A Case Study of Indonesia. Law, Environment and Development Journal, 7, 117-130.

[31] USAID (2012) Property Rights and Resource Governance in Indonesia. http://www.usaidlandtenure.net/sites/default/files/country-profiles/full-reports/USAID_Land_Tenure_Indonesia_Profil e_0.pdf

[32] Abdulai, A., Owusu, V. and Goetz, R. (2011) Land Tenure Differences and Investment in Land Improvement Measures: Theoretical and Empirical Analyses. Journal of Development Economics, 96, 66-78. http://dx.doi.org/10.1016/j.jdeveco.2010.08.002

[33] Counsel, S. (2006) Forest Governance in the Democratic Republic of Congo: An Ngo Perspective. http://www.fern.org/sites/fern.org/files/media/documents/document_3663_3664.pdf

[34] USAID (2010) PropertyRights and Resouce Governance in Democratic Republic of Congo. http://usaidlandtenure.net/democratic-republic-of-congo

[35] Boakye, K.A. and Baffoe, K.A. (2006) Trends in Forest Ownership, Forest Resource Tenure and Institutional Arrangements: Resource Management Support Centre, Forestry Commission of Ghana. http://www.fao.org/forestry/12505-01d2e95c6b96016463fe58818c7e9c29d.pdf

[36] USAID (2010) Property Rights and Resource Governance in Nigeria. http://usaidlandtenure.net/sites/default/files/country-profiles/full-reports/USAID_Land_Tenure_Nigeria_Profile.pdf

[37] USAID (2012) Property Rights and Resource Governance in Ghana. http://usaidlandtenure.net/sites/default/files/country-profiles/full-reports/USAID_Land_Tenure_Ghana_Profile_0.pdf

[38] GGSLN (1983) A Law for the Preservation and Control of Forests. Gongola State Law of Nigeria, CAP, 56.

[39] RRI (2015) Nigeria: Rights and Resources Initiatives. http://www.rightsandresources.org/documents/files/doc_4690.pdf

[40] Lam, M.K., Tan, K.T., Lee, K.T. and Mohamed, A.R. (2009) Malaysian Palm Oil: Surviving the Food versus Fuel Dispute for a Sustainable Future. Renewable and Sustainable Energy Reviews, 13, 1456-1464. http://dx.doi.org/10.1016/j.rser.2008.09.009

[41] Goodchild, M.F. and Glennon, J.A. (2010) Crowdsourcing Geographic Information for Disaster Response: A Research Frontier. International Journal of Digital Earth, 3, 231-241. http://dx.doi.org/10.1080/17538941003759255

[42] Jokar Arsanjani, J., Helbich, M., Bakillah, M. and Loos, L. (2015) The Emergence and Evolution of OpenStreetMap: A Cellular Automata Approach. International Journal of Digital Earth, 8, 76-90. 
[43] Noordegaaf, J., Barthalomew, A. and Eveleigh, A. (2014) Modeling Crowdsourcing for Cultural Heritage. MW2014: Museums and the Web 2014. http://mw2014.museumsandtheweb.com/paper/modeling-crowdsourcing-for-cultural-

[44] Tulloch, D. (2014) Crowdsourcing Geographic Knowledge: Volunteered Geographic Information (Vgi) in Theory and Practice. International Journal of Geographical Information Science, 28, 847-849. http://dx.doi.org/10.1080/13658816.2013.873440

[45] EROS (2003) Slc-Off Scientific Usability: Preliminary Assessment of the Value of Landsat 7 Etm+ Data Following Scan Line Corrector Malfunction. http://landsat.usgs.gov/documents/SLC_off_Scientific_Usability.pdf

[46] Tappan, G. and Cushing, M. (2004) Use of SLC-Off Landsat Image Data for Monitoring Land Use/Land Cover Trends in West Africa. http://landsat.usgs.gov/documents/landcover_landuse_slcoff_tappan.pdf

[47] Chen, J., Zhu, X., Vogelmann, J.E., Gao, F. and Jin, S. (2011) A Simple and Effective Method for Filling Gaps in Landsat Etm+ SLC-Off Images. Remote Sensing of Environment, 115, 1053-1064. http://dx.doi.org/10.1016/j.rse.2010.12.010

[48] Cheng, J. (2003) Modelling Spatial and Temporal Urban Growth. PhD Thesis, International Institute for Geo-Information Science and Earth Observation, Enschede.

[49] Bingham, N.H. and Fry, J.M. (2010) Regression: Linear Models in Statistics. Undergraduate Mathematics Series, Springer, London. 